\title{
Manuscrito aceito
}

\section{Louis Pasteur e a revolução bacteriana}

Mittie Tada L.R.F. Brasil ${ }^{1}$, Olga Sofia Faberge ${ }^{1}$, Nelson Ibañez ${ }^{1}$

${ }^{1}$ Pesquisadores do Laboratório de História da Ciência do Instituto Butantan.

Este texto foi avaliado e aceito para publicação. Ele está em processo final de publicação e pode sofrer alterações.

O texto é considerado publicado na edição 14(1) dos Cadernos de História da Ciência e está registrado com o DOI: https://doi.org/10.47692/cadhistcienc.2020.v14.34758

\section{Cadernos de História da Ciência}

Instituto Butantan

\section{Introdução}

A carreira científica de Louis Pasteur foi bastante produtiva e trouxe importantes conhecimentos a variados campos da Ciência. A contribuição que o colocou entre os maiores cientistas dos tempos modernos está ligada à descoberta de vacinas que mudaram os rumos da medicina e da saúde pública, mostrando-se essenciais ainda hoje e modificadas pelas inovações tecnológicas, que the proporcionou mais eficácia e menos efeitos colaterais. Persiste, sobretudo, a concepção inicial de que se poderia mudar o curso natural das doenças por meio de intervenções simples como o uso da vacina que, obtida em escala industrial, revolucionou o campo da prevenção.

Ciência e tecnologia costumam resultar dos esforços de muitas pessoas interessadas no seu avanço, o que inclui não somente pesquisadores e inventores, mas também a sociedade em geral, a indústria (em busca de aumento qualitativo ou quantitativo da produção) e o comércio (pela possibilidade de uma oferta diversificada e competitiva). Assim, diversos setores da atividade humana se envolvem e são beneficiados em maior ou menor grau. Além do envolvimento de um grande número de pessoas - às vezes de diferentes momentos históricos -, produtos ou processos acabados também podem demandar longos períodos de experimentos, construção de protótipos, testes de segurança e de qualidade e outros atributos perseguidos ou exigidos pela sociedade de consumo, o que mobiliza grandes recursos humanos e materiais. À toda essa 


\section{Manuscrito aceito}

multiplicidade, que envolve os processos de inovação na sociedade humana, somam-se as contribuições individuais como as de Louis Pasteur e de tantos outros cientistas que o precederam ou the foram contemporâneos. Estudar a vida e as atividades desses indivíduos, para além da constatação de sua relevância histórica, é uma tentativa de resgate das raízes da complexidade que envolve, nos dias de hoje, a atuação humana nos processos de criação e inovação científicas.

\section{O século XIX e a Ciência}

Louis Pasteur nasceu no início do século XIX, um período bastante fértil para as Ciências, principalmente as Biológicas. O período em que se iniciou a construção da chamada Ciência Moderna remonta ao século XV, à Renascença e o surgimento de novas ideias se contrapondo ao Período Medieval. O historiador John D. Bernal dividiu esse período inicial em três fases: a primeira vai de 1440 a 1540, a segunda de 1540 a 1650 e a terceira de 1650 a 1690. Depois, inicia-se o período dos séculos XVIII e XIX, que ele considera de florescimento industrial e de grandes conquistas tecnológicas e científicas que deram formato ao mundo moderno atual.

Os três períodos iniciais citados por Bernal caracterizam o longo processo que vai da transição da Era Medieval ao Período Moderno. São traços dessa transição, do ponto de vista econômico e social, o início das grandes navegações, o crescimento das cidades, intensa troca comercial, o surgimento e fortalecimento da burguesia e dos alicerces do capitalismo e grandes modificações na produção manufatureira, como a utilização do carvão vegetal para a produção de aço em larga escala. A procura por uma alternativa energética levou o carvão mineral e a antiga atividade carvoeira familiar e restrita à substituição por grandes empreendimentos mineradores. Mais à frente houve a introdução da máquina à vapor, um dos fatores importantes para a Revolução Industrial que alteraria e aprofundaria as mudanças econômicas e sociais dos séculos XIX e XX.

Do ponto de vista das Ciências, o traço maior da transição está na ruptura do domínio da Igreja sobre a Ciência, o que se deu de forma lenta, mas irreversível, à medida que novos conhecimentos eram descobertos e incorporados pela prática científica. Esta ruptura se deu no campo das explicações da Ciência e não necessariamente no campo das crenças religiosas dos cientistas. Pasteur, por exemplo, era católico, fato que não interferiu em sua 


\section{Manuscrito aceito}

prática científica.

É longa a lista de cientistas desse período que contribuíram decisivamente para que a laicização ocorresse, retomando a chamada Ciência Clássica (Período Greco-Romano) e dando um valor especial ao método científico: à observação direta e com instrumentos cada vez mais apropriados; à mensuração e quantificação dos fenômenos naturais, primeiro com a Matemática e depois com aparelhos que ajudariam a medir as distâncias na astronomia; à velocidade e energia na Física; as substâncias químicas e, por fim que a experimentação fosse "inventiva" ou ao acaso, "alquímica" de Paracelso ou resolutiva de Galileu.

Retomemos o período dos séculos XVIII e XIX. Estes séculos se caracterizaram pelo grande crescimento das indústrias e do capitalismo industrial com o auxílio das novas tecnologias, que aumentavam cada vez mais a produção por meio da mecanização. No início desta época temos Voltaire, que com Elementos da Filosofia de Newton introduziu a Física newtoniana na França; e Leibniz, que difundiu as academias científicas pela Europa. Vários países além da Inglaterra e da França se engajaram na construção da Ciência. Exemplos são os países nórdicos, que se voltaram para o estudo de seus recursos naturais. Em particular a Rússia, que sob Pedro, o Grande, pretendia construir uma "ciência russa" na qual se destacou Lomonosov, físico e poeta que liderou grandes cientistas russos. Newton já tornara importantes as disciplinas científicas da Astronomia e da Matemática. Vale lembrar o papel de Benjamin Franklin com seus estudos sobre a eletricidade e sua invenção do para-raios. Na botânica, Lineu propiciou a grande difusão dos herbolários e suas preparações medicinais. É desse período também o grande crescimento das coleções do Museu Britânico.

Surge também na França a famosa enciclopédia de Diderot e D'Alembert, reunindo os conhecimentos científicos e de manufatura, os pensamentos da época e a cultura em geral, proporcionando a divulgação destes conhecimentos.

Lavoisier sistematizou o estudo da Química, racionalizando as fórmulas químicas e suas descrições e permitindo também predições sobre novas substâncias. Prietley, pároco inglês que descobriu o oxigênio, também influenciou Lavoisier em sua construção da Química como Ciência. É desse período também a fundação da Escola Normal Superior, onde Pasteur estudaria e, ao final de sua carreira, criaria o laboratório que daria origem 


\section{Manuscrito aceito}

ao Instituto Pasteur. Surge também a Escola Politécnica de Paris com a finalidade de formar engenheiros, pois o crescimento industrial e seu aprimoramento necessitavam de mão-de-obra mais qualificada.

Paralelamente, vamos encontrar as contribuições de Faraday e a eletrólise; a química orgânica de Berzelius; a teoria atômica de Dalton; a lei ou princípio de Avogadro; as teorias e descobertas de Pasteur, que serão relatadas mais adiante; além dos evolucionistas como Darwin e Lamarck e a polêmica que cercou a teoria da geração espontânea. Coincide também com o surgimento da medicina científica introduzida por Pasteur e suas vacinas, a química fisiológica de Claude Bernard. Bernard estudou o complexo conjunto de atividades dos seres vivos que mantinham o equilíbrio com o meio externo mesmo em condições adversas; e seu estudo sobre os movimentos musculares e os nervos abriu caminhos para o estudo do sistema nervoso central. Finalmente, destacam-se as inovações na agricultura, que trouxeram a possibilidade de aumento da produção agrícola e, assim, de alimentar a população em crescimento.

Chegando ao final do período dos séculos XVIII e XIX, observa-se que as conquistas científicas acumuladas nessa época contribuíram para dar a conformação do mundo atual com o crescimento e a consolidação do capitalismo e da produção industrial. Embora, segundo Bernal, a ciência não seja necessariamente a responsável por esse processo - a despeito da máquina à vapor, que alavancou substancialmente a produção industrial e que se consolidou pelo fortalecimento do capitalismo através do sistema financeiro e de produção.

O início da Revolução Industrial contou com a contribuição dos chamados "inventores" no aperfeiçoamento das máquinas. Ao mesmo tempo, à medida que a complexidade dos problemas a serem resolvidos se manifestava, a figura do cientista foi sendo cada vez mais requisitada e, aliada à do inventor, operava nas mudanças tecnológicas.

Não se pode esquecer que de muitos fatores influenciaram no crescimento da ciência. Exemplos são as mudanças na própria sociedade com a ascensão de novos grupos hegemônicos; as guerras; o desejo de controlar e prevenir antigas e novas doenças; a ampliação de horizontes ocasionada pelas descobertas de novas culturas; produtos de consumo até então desconhecidos e encontrados nos novos continentes; a instalação de novas ordens econômicas e políticas; além da determinação e do talento dos próprios 


\section{Manuscrito aceito}

cientistas. Cada um desses fatores seria merecedor de longa explanação, o que não é a proposta deste texto.

Pode-se considerar que as conquistas científicas são quase sempre frutos de construção coletiva, da interdependência entre os pesquisadores que trabalham em laboratórios distantes, assim como da progressão acumulada ao longo do tempo. Assim, este resumo histórico introdutório teve a finalidade de contextualizar o período em que Pasteur viveu e produziu, época em que o acúmulo de conhecimento proporcionava as condições básicas necessárias, em termos teóricos e tecnológicos, para o seu desenvolvimento científico.

\section{Breve biografia de Pasteur}

Louis Pasteur nasceu em Dole, na França, em 27 de dezembro de 1822. Foi o terceiro filho de Jean Joseph Pasteur e Jeanne Etiennette Roqui. Pelo lado paterno a família provinha de pequenos arrendatários rurais, que depois se tornaram moleiros no século XVIII e, mais adiante, proprietários de pequenos curtumes. Pasteur tinha três irmãs e um irmão mais velho, que faleceu ainda muito jovem. Seu pai serviu o exército sob Napoleão Bonaparte e recebeu a Cruz da Legião de Honra, o que the causava grande orgulho. Quando Pasteur tinha cinco anos, sua família mudou-se para Arbois, onde alugaram outro curtume. Por sua criação em família tradicional, Pasteur manteve ao longo da vida os valores da pequena burguesia, como o respeito ao trabalho, à família e, principalmente, a preocupação pela estabilidade financeira. Ainda jovem, Pasteur mostrou pendores artísticos, chegando a pintar quadros que hoje estão expostos no Museu do Instituto Pasteur. No entanto, para sua família a carreira artística não era promissora e seu pai o matriculou no Colégio de Arbois para colocá-lo no caminho do magistério.

Para seguir a carreira de professor na França da época, a Escola Normal Superior de Paris era a mais indicada, mas exigia preparo prévio, pois os exames de admissão eram bastante exigentes. Para esse período preparatório, ele ingressou no Colégio Real de Besançon onde, além de estudante, foi nomeado monitor, o que o ajudava a pagar suas despesas.

$\mathrm{Na}$ primeira tentativa para ingressar na Escola Normal aos 20 anos de idade, em 1842, Pasteur se classificou em 15ำ lugar, considerado insatisfatório por ele próprio, que resolveu se preparar durante mais um ano para buscar melhor classificação que lhe 


\section{Manuscrito aceito}

garantisse uma bolsa integral de estudos. Isso aconteceu no ano seguinte, já que conseguiu se classificar em 40 lugar. Este episódio já dava mostras de seu caráter competitivo e determinado, características de sua personalidade que se tornariam evidentes ao longo de sua vida em muitos desafios científicos. Ainda em 1842 foi reprovado na Escola Politécnica de Paris, importante instituição de ensino de Engenharia - apenas um incidente que, de certa forma, definiu seus caminhos futuros. Entre 1843 a 1848 estudou e trabalhou na Escola Normal e prestou dois exames nacionais de qualificação para exercer o magistério, nos quais foi aprovado. Em 1847 terminou o doutorado em Ciências e continuou atuando como assistente de pesquisa em Química enquanto aguardava nomeação para uma escola. O seu interesse pela pesquisa já era evidente, atestado por seus estudos iniciais sobre cristais, sua composição química e sua atividade óptica.

Em 1848 eclodiu a revolução que antecedeu a Segunda República Francesa. Pasteur serviu durante algum tempo na Guarda Nacional, onde contribuiu com suas poucas economias em favor dos republicanos. No mesmo ano, sua mãe adoeceu e faleceu repentinamente, deixando Pasteur consternado. Isso motivou seu pedido de nomeação para alguma escola da província para ficar próximo à sua família, sendo indicado para o Liceu de Dijon. Como estava desenvolvendo uma pesquisa sobre o ácido tartárico e ácido racêmico, foi-Ihe permitido permanecer ainda algum tempo na Escola Normal até finalizar seus estudos.

Permaneceu pouco tempo em Dijon, sendo logo nomeado professor adjunto de Química na Faculdade de Ciências de Estrasburgo. Lá conheceu Marie Laurent, filha do reitor da Academia de Estrasburgo, com quem se casou em 29 de maio de 1849.

\section{O início do percurso científico e sua primeira descoberta}

Durante os seis anos que permaneceu em Estrasburgo, Pasteur deu continuidade aos estudos que culminaram na sua descoberta sobre o comportamento óptico inusitado de compostos com a mesma composição química, que respondiam de forma diferente à luz polarizada (no caso, os tartaratos e paratartaratos). Pasteur encontrou a explicação para tal diferença de comportamento ao descrever que as duas substâncias - no caso, o tartarato de amônio e sódio e o paratartarato de amônio e sódio - tinham a mesma composição química, mas com estruturas diferentes. Assim, pela incidência da luz 


\section{Manuscrito aceito}

polarizada, a primeira desviava o feixe luminoso para a direita (dextrogiro) e a segunda não desviava a luz. Pasteur provou que o paratartarato era composto por duas substâncias de mesma fórmula química, porém, eram estruturalmente especulares, sendo que uma delas desviava a luz para a direita (dextrogiro) e a outra para a esquerda (levogiro). Ademais, provou que o composto formado pela mistura das duas substâncias era indiferente ao efeito óptico. A comunicação que Pasteur fez desses resultados causou bastante sucesso no meio científico, rendendo-Ihe uma premiação de 1.500 francos da Sociedade de Farmácia e a condecoração da Legião de Honra Francesa, que homenageava quem "engrandecia a nação".

Por que essa descoberta de Pasteur se revestiu de grande importância? Acontece que na época, outros cientistas, como Eilhard Mistscherlich, já haviam descrito esse fenômeno, mas não conseguiam explicá-lo, pois se acreditava que compostos químicos de mesma natureza, mesma proporção e com mesma disposição dos átomos deveriam ser idênticos. A diferença entre essas duas substâncias era muito sutil e escapou à observação de vários pesquisadores. O processo de trabalho de Pasteur para chegar a esse resultado foi de grande intensidade, como atestam suas notas pessoais nos cadernos onde registrava seus testes de laboratório e suas observações. Passo a passo, construía os modelos e teorias que, posteriormente, resultariam em publicações.

\section{Cadernos de nota}

Aqui é importante introduzir uma pequena explicação sobre o que são os cadernos de notas de Pasteur. São cadernos que se constituíam de registros detalhados de seus experimentos em laboratório. Era também onde ele anotava ideias, fracassos e sucessos, esboços de projeto e assuntos afins. Registrou passo a passo e dia a dia seu cotidiano do laboratório, das reuniões com sua equipe de trabalho e dos experimentos realizados. Ele considerava que esses registros eram pessoais e não permitia que ninguém os consultasse, nem mesmo seus assistentes. Em determinado momento de sua vida, mais especificamente em 1878, aos 55 anos, Pasteur pediu à família que seus cadernos de notas particulares de laboratório nunca fossem divulgados. Vários fatores influenciaram essa decisão que, aparentemente, foi desencadeada por uma polêmica em que Pasteur esteve envolvido. Ela ocorreu devido a uma nota publicada por Berthelot, assistente de Claude Bernard, extraída do caderno de notas desse importante cientista, expoente da medicina experimental e muito amigo de Pasteur. A nota publicada aparentemente 


\section{Manuscrito aceito}

contradizia a teoria microbiana da fermentação bastante defendida por Pasteur, que ignorava o fato de que Bernard tivesse registrado tais ideias pelo simples fato de o amigo, em vida, jamais ter abordado o assunto. Sentindo-se na obrigação de rebater publicamente, Pasteur não culpou Claude Bernard, e sim o assistente, por ter publicado algo que ainda estava no campo das ideias, sem comprovação científica e em estágio preliminar. O pedido de Pasteur de não divulgarem suas notas talvez tenha sido motivado por temer críticas a seus métodos de trabalho, semelhantes às que ele fora obrigado a fazer ao amigo Bernard. Sua vontade foi respeitada até 1964 durante quase cem anos, quando seu neto e último descendente, Dr. Pasteur Vallery-Radot, entregou à Biblioteca Nacional de Paris todo seu acervo documental. Somente em 1985 foi disponibilizado o catálogo impresso da coleção de cujo acervo fazem parte os 140 cadernos escritos pelo próprio Pasteur, além de notícias, cartas, apontamentos de aulas, rascunhos, esboços de projetos, entre outros.

O historiador Gerald Geison, professor de História da Ciência de Princeton, se debruçou sobre parte dos cadernos e trouxe à luz o processo de construção da Ciência utilizado por Pasteur. Destacando alguns tópicos de grande interesse para os aficionados da História da Ciência, essa pesquisa resultou no livro "A Ciência particular de Louis Pasteur". O estudo dos cadernos de notas mostra que algumas descobertas de Pasteur não dependeram apenas de seu tirocínio e talento científico, mas resultaram de sua determinação, sua disposição ao trabalho, de uma inquestionável capacidade de liderança e, principalmente, da atuação de seus assistentes. A questão do acaso não se confirma nas descobertas pasteurianas. Tudo segue um padrão de muita busca e muitas tentativas, erros e acertos, e da significativa contribuição de seus assistentes, o que não aparecia claramente em seus textos quando publicados.

\section{A Ciência básica e a inovação}

Retomando a cronologia profissional, ao final de 1854, Pasteur deixa Estrasburgo e vai para Lille, onde é nomeado professor catedrático de Química da Faculdade de Ciências recém-criada por decreto imperial, cuja finalidade era unir os esforços da pesquisa à produção industrial. Ela deveria também formar profissionais qualificados para trabalhar nas indústrias. Todas as disciplinas dispunham de laboratórios e todos os alunos tinham aulas teóricas e práticas. Pasteur defendia que a faculdade deveria ter o cuidado de 


\section{Manuscrito aceito}

sempre aliar a prática à teoria (a Ciência básica à serviço das inovações), para que a formação do estudante fosse completa. Para fortalecer os vínculos entre a faculdade e as indústrias, ele costumava levar seus alunos para visitá-las, além de demonstrar nos laboratórios processos industriais como o branqueamento do açúcar, a fermentação do álcool e dos vinhos. É dessa época seu interesse pela fermentação, o que é demonstrado pelas visitas periódicas que fazia a uma fábrica de álcool.

\section{Retorno à Escola Normal}

Ao final de 1857, Pasteur reivindicou o cargo de Diretor de Estudos Científicos da Escola Normal de Paris, cargo que conseguiu com o compromisso de elevar novamente a escola aos patamares de importância que ela havia tido no passado. Apesar das atribuições do cargo - que envolvia funções administrativas e financeiras da instituição -, Pasteur ainda mantinha grande interesse pela pesquisa científica. Assim, para evitar a descontinuidade de seus estudos, improvisou um pequeno laboratório, onde continuou suas pesquisas sobre fermentação. Aos poucos ele foi ampliando e equipando o laboratório, o que ainda era muito pouco para suas ambições de cientista. Ele necessitava de investimentos regulares não só para ampliação do espaço como para a contratação de assistentes e compra de materiais. Foi então que sua proximidade com o imperador Luís Napoleão permitiu certa estabilidade no aporte de recursos. Além de verbas públicas oriundas do Ministério da Educação, ele conseguiu que doadores privados ou voluntários contribuíssem para suas pesquisas.

Nessa época, Pasteur já era reconhecido e respeitado por sua ciência a ponto de muitos alunos preferirem a Escola Normal à Escola Politécnica, tamanha a importância que a instituição atingiu sob sua direção. Porém, devido à sua rigidez e conservadorismo, Pasteur protagonizou uma situação dramática que causou a sua saída da diretoria da Escola Normal. O fato aconteceu em 1867, em um momento de grandes discussões no parlamento sobre a liberdade de pensamento. Segundo as regras da Escola Normal, era proibida qualquer manifestação política por parte dos alunos; nestes casos os infratores eram passíveis de punição. O fato de um estudante ter escrito um manifesto de apoio político a um senador pela liberdade de pensamento e tê-lo publicado foi o suficiente para que fosse solicitada sua expulsão. Isto causou grande revolta entre os alunos, que levaram a sua indignação às ruas de Paris com grande tumulto. Como resultado, a escola foi fechada e Pasteur foi demitido da função. 


\section{Manuscrito aceito}

Ele foi, então, nomeado catedrático de Química Inorgânica na Sorbonne, onde permaneceu de 1867 a 1874. Além disso, ele reivindicou ao imperador que financiasse um novo laboratório de Química Fisiológica na Escola Normal para dar continuidade às suas pesquisas, no que foi prontamente atendido. Em 1868 iniciou-se a construção do novo laboratório, que seria ligado ao antigo por meio de uma galeria. A guerra francoprussiana, porém, atrapalhou bastante a conclusão do projeto e, durante a guerra, Pasteur se mudou para o interior, onde se dedicou ao estudo da cerveja.

Durante todo o tempo em que administrou a Escola, ele nunca se descuidou de suas pesquisas. Foi desse período - de 1865 a 1870 - o estudo sobre as doenças do bicho-daseda, e é praticamente da mesma época a publicação dos Annales Scientifique de L'Ecole Normale Superieure, revista criada com a finalidade de publicar os trabalhos produzidos na Escola Normal.

Em 1871 pleiteou aposentadoria, alegando que desde que fora tutor em Besançon já completara trinta anos de magistério. Ademais, se considerava merecedor de uma recompensa por suas contribuições científicas à nação. Em 1874, a Assembleia Nacional Ihe conferiu uma recompensa anual de 12 mil francos, que correspondia ao seu salário de professor na Sorbonne.

Em 1875 fez uma incursão política ao se candidatar ao Senado por Arbois, defendendo ideias conservadoras contra os republicanos. Mas não conseguiu se eleger. Lamentava também pela abdicação de Luís Napoleão, que Ihe prometera uma cadeira no Senado, assegurando-Ihe, dessa forma, proventos que the permitiriam uma vida tranquila. No entanto, mesmo no governo republicano que se instalou pós Luís Napoleão, Pasteur conseguiu manter seu prestígio respaldado pela respeitabilidade enquanto cientista e nacionalista que construiu desde o início de sua carreira.

Permaneceu como diretor do Laboratório de Química da Escola Normal de 1867 a 1888, quando este passou a integrar o Instituto Pasteur, construído ao lado. Dirigiu, então, o Instituto Pasteur até seu falecimento em setembro de 1895. 


\section{Manuscrito aceito}

\section{Dos cristais à Biologia: a caminho das vacinas}

No período em que esteve à frente da Escola Normal e do Laboratório, Pasteur empreendeu várias pesquisas, retomando e dando continuidade aos estudos iniciados na própria Escola quando ainda era estudante. Do estudo sobre os cristais passou ao da fermentação, que fundamentaria sua teoria microbiana sobre os muitos processos biológicos que observou. Mas como o químico brilhante e inicialmente estudioso de cristais, ele teria se transformado no pesquisador de uma nova disciplina a que podemos denominar Ciências Biológicas? Como se deu a passagem dos cristais e compostos inanimados para microscópicos seres vivos?

Pode-se dizer que essa transição foi progressiva se considerarmos que os cristais que ele estudou eram substâncias de origem orgânica, e que suas observações, naturalmente, derivaram para estudos sobre a fermentação. Daí ele caminhou rumo à construção da teoria microbiana da fermentação. Aqui vale um pequeno parênteses sobre a polêmica em que Pasteur esteve envolvido durante bastante tempo contra a teoria da geração espontânea.

\section{Fermentação e geração espontânea}

O tema da fermentação, que embasou suas teorias sobre as transformações que ocorrem em seres vivos causadas por outros seres vivos microscópicos, motivou longos debates e polêmicas em que Pasteur se envolveu durante boa parte da sua carreira de cientista.

Para entender melhor esse assunto, é necessário recuperar as ideias que predominavam no meio científico da época sobre a questão da origem da vida. Enquanto Pasteur estava formulando sua teoria microbiana na fermentação, considerando-a, portanto, um processo de atividade biológica, o naturalista francês Pouchet defendia a teoria de geração espontânea. É também da mesma época o livro de Darwin sobre as origens das espécies, outro gerador de grandes polêmicas não só na Ciência, como na religião e na política. As academias de Ciências, então, fervilhavam com debates pró e contra estas teorias.

A polêmica entre Pasteur e Pouchet se tornou mais evidente a partir de 1858, quando Pouchet afirmava ter provas sobre a geração espontânea. Mas Pasteur demonstrou, de 


\section{Manuscrito aceito}

forma magistral, os equívocos não percebidos por Pouchet em seus experimentos. Para isso ele usou urina e sangue sem contaminação em condições de esterilidade e que não se decompuseram, provando que os agentes da putrefação não surgiam por geração espontânea, mas que estavam no meio ambiente e eram disseminados pelo ar. Essas e outras descobertas de Pasteur lhe carrearam muita popularidade.

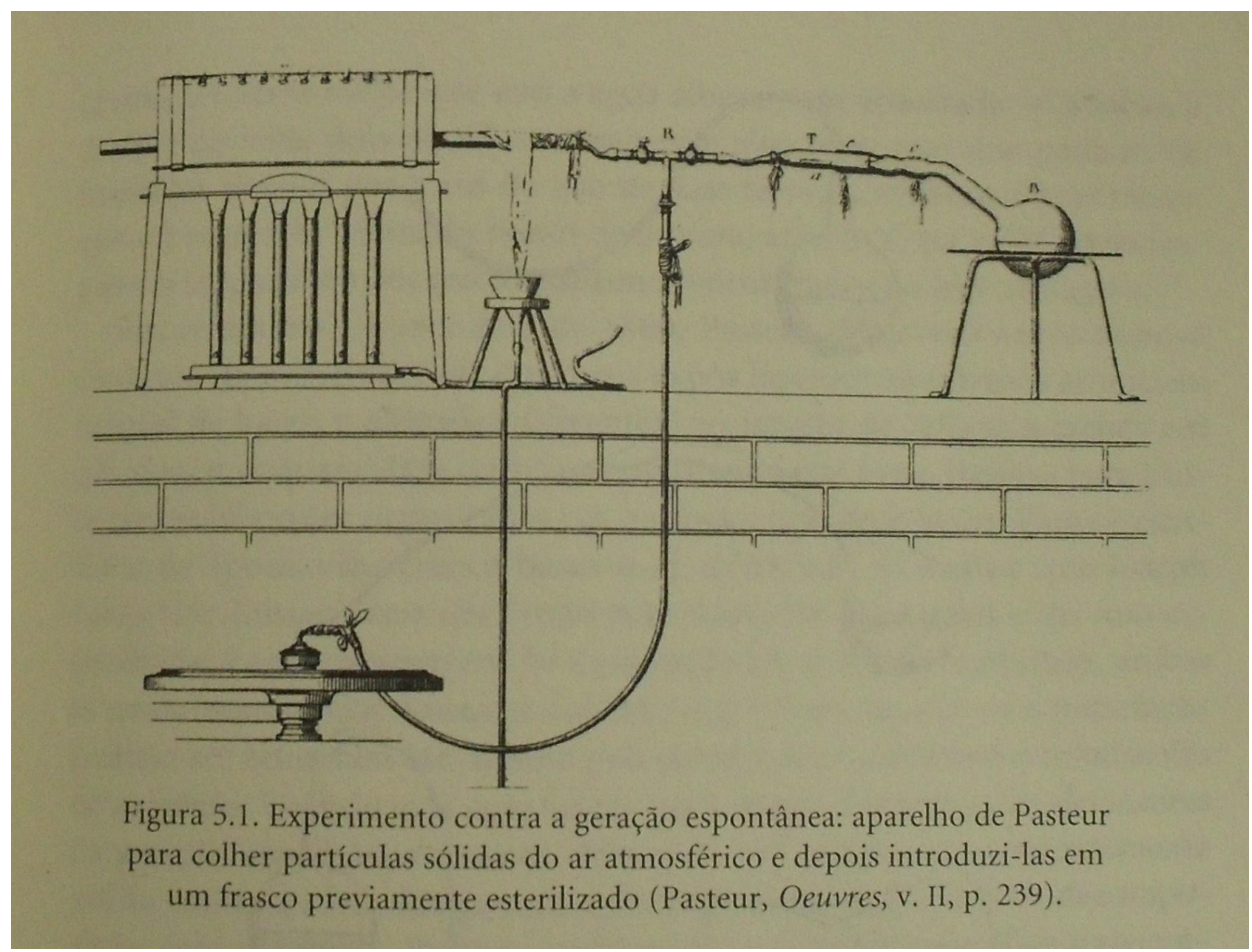

Fonte: Geison, G. A ciência particular de Louis Pasteur. Rio de Janeiro: Editora FIOCRUZ 2002, p. 139

\section{Aliando Ciência e economia}

Pasteur conduziu sua carreira de cientista e produtor de soros e vacinas aliando a construção do conhecimento científico à produção em larga escala de insumos que poderiam beneficiar grande número de pessoas. Preveniu a morte com a vacina antirrábica e doenças em animais, interferindo, dessa forma, diretamente na economia. 


\section{Manuscrito aceito}

Pasteur estudou durante cinco anos as doenças do bicho-da-seda, trazendo soluções para os problemas dos sericultores. Depois avançou no campo das doenças das aves. No caso, debruçou-se sobre a cólera das galinhas, que causava grandes prejuízos aos criadores e para a qual desenvolveu uma vacina.

Como se percebe, Pasteur tinha uma imagem muito vinculada a de um cientista comprometido com os problemas da sociedade, colocando-se à procura de respostas que melhorassem os processos de produção e aumentassem sua rentabilidade. Esta imagem de cientista preocupado em explicar os fenômenos e, ao mesmo tempo, em buscar soluções factíveis, ajudou a popularizar a Ciência e a figura do cientista como detentor do saber, humanitarista e nacionalista. Sempre, em seus discursos, Pasteur se colocava a serviço da França e defendia que suas conquistas contribuiriam para aumentar o prestígio de seu país. Sentia-se obrigado a disputar resultados com seus "adversários" cientistas, principalmente os alemães, pois nutria intenso sentimento antiprussiano, resultado da guerra franco-prussiana na qual teve pequena, mas patriótica participação.

Voltando às realizações científicas de Pasteur, após resolver o problema da cólera das galinhas, apresentou-se para ele outra questão: a carbunculose dos carneiros, uma doença transmissível que causava grandes prejuízos aos criadores. Este fato merece descrição mais atenta por testar relacionado ao aumentado do prestígio que Pasteur já usufruía junto à opinião pública. Ao enveredar pelas pesquisas sobre doenças infectocontagiosas, Pasteur encontrou um caminho fértil e altamente compensador como cientista. A carbunculose já estava sendo estudada por Robert Koch que, inclusive, já publicara um artigo sobre sua etiologia microbiana, tornando-a a primeira doença infecciosa em animais de grande porte a ter sua etiologia ligada a um agente bacteriano. Pasteur também desenvolveu estudos sobre a etiologia dessa doença, reforçando a mesma tese defendida por Koch.

Pasteur e sua equipe passaram a se dedicar ao grande desafio de conseguir uma forma de prevenção à doença através da obtenção de uma vacina. Graças aos resultados alcançados com a vacinação das galinhas, ele pleiteou apoio para dar continuidade aos estudos sobre a nova vacina, assim como para a ampliação do laboratório. Recebeu o financiamento necessário para garantir a continuidade de suas pesquisas e, no final de 1881, anunciou a descoberta de vacina contra o carbúnculo. 


\section{Manuscrito aceito}

Conta a história que Pasteur foi desafiado por Hypollite Rossignol a testar sua vacina nos carneiros de sua fazenda na frente de políticos e jornalistas de forma a provar que ela, de fato, protegia contra o carbúnculo. Em resumo, o teste iniciou-se com sessenta carneiros. Dez animais foram separados, não receberam nenhuma dose da vacina e nem foram inoculados com o carbúnculo. Vinte e cinco foram vacinados com duas doses em intervalo de 12 dias entre as aplicações. Outros vinte e cinco carneiros não receberam nenhuma dose da vacina. Após vinte e cinco dias da primeira aplicação da vacina, ambos os lotes tanto vacinados quanto não vacinados - receberam uma injeção de cultura de carbúnculo letal. Após dois dias, no famoso dia 2 de junho, os animais foram submetidos à observação pública. O resultado: dos vinte e cinco carneiros não vacinados, vinte e três estavam mortos e dois moribundos; por outro lado, dos vinte e cinco animais vacinados, apenas uma ovelha prenhe estava morta. Isto comprovava que a vacina era eficaz.

Na época, Pasteur já defendia a ideia de que microrganismos atenuados poderiam ser usados como agentes imunizantes, seguindo o modelo da vacina antivariólica de Jenner. Mas os cadernos de notas de Pasteur revelam que a vacina usada na experiência não era aquela que ele estava desenvolvendo. Ele partira do pressuposto de que o oxigênio era um bom agente atenuante, mas seus experimentos em animais de laboratório não corroboravam sua tese. Devido à premência do prazo, utilizou a vacina atenuada por bicromato de potássio obtida por Chamberland, seu assistente. O protocolo do experimento para observação pública contou com o aval da Sociedade de Agricultura de Melum e o fato de a vacina usada não ter sido a desenvolvida pelo próprio Pasteur em nada quebrou o protocolo. Fica, porém, a questão: por que o cientista não divulgou que a vacina usada tinha sido a de seu assistente? Independente dessa questão, a repercussão do experimento ajudou a reforçar as verbas do laboratório e lhe permitiu dar continuidade às suas pesquisas sobre as doenças infectocontagiosas.

\section{Em busca de solução para a raiva humana}

O passo seguinte seria perseguir uma vacina eficaz e segura contra a raiva humana. A história conta que, desde a infância, Pasteur se sentia sensibilizado pelos casos de raiva humana que havia presenciado. Sabia-se que todo caso manifesto da doença era considerado como morte certa. A medicina da época preconizava cauterização da área inicialmente infectada com ferro em brasa, o que causava grande sofrimento às vítimas 


\section{Manuscrito aceito}

submetidas a este "tratamento".

Porém, o motivo que de fato o levou a enveredar por este caminho de pesquisa foi a solicitação do Dr. Lannelongue do Hospital Sainte-Eugène para que ele visse uma criança que fora internada com hidrofobia. O menino apresentava todos os sinais clássicos da doença e morreu no dia seguinte. Pasteur coletou amostras da saliva da criança, sendo que esta foi diluída em água e injetada em dois coelhos que morreram trinta e seis horas depois. Ele observou ainda que o sangue coletado destes animais continuava letal tanto para coelhos quanto para cães. Um pesquisador contemporâneo de Pasteur, Victor Galtier, da Escola de Veterinária de Lyon, também dedicado ao estudo da raiva animal, havia obtido resultados interessantes transmitindo a raiva de cães para os coelhos. Como o período de incubação em coelhos era bem menor do que em cães, o que facilitava os experimentos de laboratório, eles se tornaram os preferidos para as inoculações.

Galtier também sugeria que o longo período de incubação da raiva poderia permitir que a vacinação fosse feita antes do aparecimento dos sintomas, prevenindo a evolução letal. Ainda observou que conseguira imunizar carneiros usando a saliva de cães hidrófobos. Esse resultado foi corroborado por Roux, assistente de Pasteur.

Pasteur e Roux usaram, no caso da raiva, a informação já constatada durante a pesquisa da vacina contra cólera das galinhas: que a passagem sucessiva de alguns microrganismos por outros seres vivos poderia aumentar ou atenuar sua virulência. Quando o efeito fosse atenuante, eles poderiam ser usados como vacina. Outro autor que relatou fenômeno semelhante foi Koch em seu estudo sobre o carbúnculo, observando o aumento de virulência pela propagação seriada.

Paralelamente às pesquisas sobre a raiva e ainda em 1883, Pasteur desenvolveu uma vacina contra a febre suína a partir do método de atenuação por propagação seriada utilizando coelhos. No decorrer das pesquisas sobre a vacina da raiva, ele testou e criou muitos métodos de laboratório para analisar a questão da virulência e o comportamento em cada situação estudada.

As publicações sobre resultados promissores de determinado experimento às vezes não deixam claro o grau de dificuldade encontrado no processo que, frequentemente, exigia muita determinação e paciência do pesquisador. Não deve ter sido fácil o caminho de 


\section{Manuscrito aceito}

Pasteur até a obtenção de uma vacina realmente protetora e segura para o uso humano. Ele tinha sérias preocupações sobre não usar o ser humano como parte dos experimentos, pois considerava essa atitude criminosa. Ele somente poderia liberar qualquer produto para uso humano se provasse a partir dos animais que, além de proteger, o processo seria seguro. Em 1885, Pasteur publica um artigo descrevendo dois casos de pessoas que tinham sido mordidas por cães hidrófobos e que tinham sido salvas por sua vacina. Esses dois casos, que ficaram famosos, foram os de Joseph Meister e Jean-Baptiste Jupille. As notas de seus cadernos de laboratório, porém, indicam dois casos anteriores em que a vacina foi utilizada: em um deles, uma criança veio a falecer; o outro era adulto e, aparentemente, sobreviveu. No caso da criança, ela já apresentava os sintomas claros da hidrofobia e hoje se sabe que, com exceção de raríssimos casos, a maioria evolui para óbito. Quanto ao adulto que teria sobrevivido, restou a dúvida para o próprio Pasteur de que, talvez, se tratasse de outra doença que não a raiva.

Vale destacar que resta, mais uma vez, a pergunta de por qual motivo Pasteur não relatou estes casos. Temia repercussões negativas sobre a vacina? Esse tipo de omissão ganha importância na medida em que o cientista, em suas pesquisas e na construção do conhecimento científico, precisa estar sempre cercado por informações e publicações de outros pesquisadores. Muitas vezes, os resultados registrados pelos pesquisadorescientistas são resumidos a algumas poucas páginas que representam anos de trabalho ou mesmo uma vida inteira de dedicação. Eles não descrevem as dificuldades enfrentadas, as soluções aplicadas e as alternativas adotadas, simplesmente relatando de forma sucinta e simplificada e seguindo padrões e normas muito restritivas das publicações científicas. Desvios, ideias, algum resultado inesperado e as soluções para vencer obstáculos imprevistos raramente aparecem nesses textos. Daí a importância dos cadernos de notas de laboratório de Pasteur, já que eles trazem com riqueza de detalhes a descrição do processo de trabalho de um reconhecido cientista.

\section{O quadrante de Pasteur}

Com o intuito de ilustrar a importância da imagem de cientista que Pasteur legou à posteridade ao aproximar e aliar sempre Ciência e técnica, pesquisa acadêmica e aplicação prática dos conhecimentos alcançados, vale citar o livro denominado "Quadrante de Pasteur" escrito por Donald Stokes. Este autor construiu um modelo que busca relacionar diferentes cenários combinando a pesquisa pura, como a busca de 


\section{Manuscrito aceito}

conhecimentos científicos, e a pesquisa aplicada, voltada para a construção de artefatos (novas armas, novos equipamentos eletrônicos, novos transportes etc.). Dividindo um quadrado em quatro quadrantes, denominou-os: quadrante de Bohr, voltado para a pesquisa pura; quadrante de Edison, quando a pesquisa tem claro objetivo prático e sem preocupação com a elaboração de conhecimentos; e denominou quadrante de Pasteur aquele que aloca as pesquisas que buscam conhecimentos, mas também consideram o uso que se poderá fazer deles. O quarto quadrante Stokes deixa sem preencher, pois qual é a pesquisa que não busca conhecimento e nem tem fins práticos?

De fato, a figura de Pasteur ficou marcada e marcou a história da Ciência pelo exercício concomitante dessas duas vertentes da produção de conhecimento: de um lado, a preocupação em estudar e teorizar sobre os fenômenos e, por outro lado, desenvolver tecnologias para uso imediato. Com sua escolha, Pasteur desenvolveu a sua teoria microbiana da fermentação e permitiu os aprimoramentos introduzidos na produção da cerveja, vinho e álcool. Gerou conhecimentos sobre o carbúnculo do carneiro, assim como participou do desenvolvimento da tecnologia que permitiu prevenir a doença e a morte desses animais. Outras vacinas surgiram e continuam surgindo, o que mostra que se tratava e ainda se trata de uma técnica robusta para a prevenção dos incontáveis males infecciosos que ameaçam a humanidade.

Percebe-se, observando a carreira científica de Pasteur e seus objetos de pesquisa, uma sequência crescente de complexidade que começa com o estudo dos cristais originados na obtenção de vinhos e vinagres, passando pelas descobertas relativas ao processo de fermentação - entremeado com a famosa polêmica entre a teoria da geração espontânea e a teoria microbiana, da qual sai vencedor. Depois vem o estudo das doenças do bichoda-seda, agora entrando definitivamente no campo da Biologia, e seguindo para a descoberta das vacinas, primeiro para os animais e depois para o homem.

Aparentemente simples quando assim relatado, o percurso científico trilhado por Pasteur envolveu longas especulações científicas e formulação de experimentos complexos. Lutou por firmar-se como um líder respeitado, construir uma imagem pública de herói nacional e conquistar o apoio efetivo das autoridades políticas. Tudo isso dá uma dimensão aproximada do que Pasteur foi capaz de construir ao longo de sua vida. A divulgação de outras informações inéditas sobre Pasteur, sob a forma das notas pessoais que trazem suas dúvidas, erros, inseguranças, em nada diminui sua estatura de cientista. 


\section{Manuscrito aceito}

Apenas agrega ao cientista a condição de ser humano.

\section{Referências}

Bernal JD. Historia social de la ciência. Barcelona: Peninsula, 1967.

Geison GA ciência particular de Louis Pasteur. Rio de Janeiro: Editora FIOCRUZ, 2002.

Raichvarg D. Louis Pasteur -“L' empire des Microbes. DeÂcouvertes”. Gallimard, 1995.

Stokes DE. O quadrante de Pasteur. Campinas: Editora da UNICAMP, 2005. 